University of Nebraska - Lincoln

DigitalCommons@University of Nebraska - Lincoln

$10-2008$

\title{
Importance of Annealing Times in the PCR Amplification of GC- Rich Genes
}

\author{
Anuradha Subramanian \\ Department of chemical Engineering,University of Nebraska Lincoln., asubramanian2@unl.edu \\ Tarlan Mamedov \\ University of Nebraska - Lincoln, tmammedov2@unl.edu \\ Elsje Pinnear \\ University of Nebraska - Lincoln \\ Hendrik J. Viljoen \\ University of Nebraska - Lincoln, hviljoen1@unl.edu
}

Follow this and additional works at: https://digitalcommons.unl.edu/cbmesubramanian

Part of the Chemical Engineering Commons

Subramanian, Anuradha; Mamedov, Tarlan; Pinnear, Elsje; and Viljoen, Hendrik J., "Importance of Annealing Times in the PCR Amplification of GC-Rich Genes" (2008). Anuradha Subramanian Publications. 8.

https://digitalcommons.unl.edu/cbmesubramanian/8

This Article is brought to you for free and open access by the Chemical and Biomolecular Research Papers -- Faculty Authors Series at DigitalCommons@University of Nebraska - Lincoln. It has been accepted for inclusion in Anuradha Subramanian Publications by an authorized administrator of DigitalCommons@University of Nebraska - Lincoln. 
Published in Journal of Biotechnology 136, Supplement 1 (October 2008), p. S100;

Biotechnology for the Sustainability of Human Society - IBS 2008 Abstracts, 13th International

Biotechnology Symposium and Exhibition. doi:10.1016/j.jbiotec.2008.07.227

Copyright ( 2008 , published by Elsevier B.V. Used by permission.

Published online October 16, 2008.

\title{
Importance of annealing times in the PCR amplification of GC-rich genes
}

\author{
Anu Subramanian, Tarlan Mamedov, Elsje Pinnear, and Hendrik Viljoen \\ University of Nebraska-Lincoln, Lincoln, Nebraska, USA \\ Corresponding author - A. Subramanian, asubramanian2@unl.edu
}

This combined theoretical and experimental study conclusively demonstrates that annealing times play a crucial role in the PCR amplification of GC-rich templates. To assist with the DNA amplification of GC-rich targets, a theory has been developed that evaluates the fraction of annealed primer/polymerase complex at the correct binding site as a function of annealing temperature and annealing period. Optimum annealing times lie in the range of 3 to $6 \mathrm{~s}$, and annealing times greater than $10 \mathrm{~s}$ yield smeared PCR amplified products. The theory has been applied to the PCR amplification of the following human cDNA templates: ARX gene (78.2\%, $660 \mathrm{bp})$, LMX1B (66.6\%, $1039 \mathrm{bp})$, FOXL2 (72.2\%, $1100 \mathrm{bp})$, and POU3F3 (73.92\%, $1503 \mathrm{bp})$. The model has been applied to the ARX gene and the results are in excellent agreement with the experimental findings (Figs. 1 and 2). The most important conclusions that can be drawn from the study are: (a) the theoretical model predicts that, in the absence of competitive binding, the efficiency of annealing is a monotone function of annealing time. Thus the theory suggests that prolonged annealing improves yield-a strategy that is followed by conventional PCR protocols, (b) there are alternative sites on the template where primers may bind, then the annealing time has a local optimum. The annealing time must be sufficiently long to form the ternary complexes at the correct template site, but too long annealing time creates the opportunity for ternary complexes to form at incorrect binding sites. Thus, PCR protocols must adopt shortened annealing times to optimize the efficiency of annealing and (c) the optimum position of the efficiency can be adjusted on the temperature-time plane within limits by changes in the primer and polymerase concentrations. But for typical primer concentrations (e.g. 10 picomole per $25 \mu \mathrm{l}$ ) and polymerase concentrations (0.5-1 EU per $25 \mu \mathrm{l})$, the optimum annealing time is in the order of 3 to $6 \mathrm{~s}$. 